\title{
Influence of Temperature on Electrical Characteristics of Different Photovoltaic Module Technologies
}

\author{
Abdul Rehman Jatoi, Saleem Raza Samo and Abdul Qayoom Jakhrani* \\ Energy and Environment Engineering Department, Quaid-e-Awam University of Engineering, Science and Technology Nawabshah, \\ Pakistan
}

\begin{abstract}
The aim of this study was to analyse the influence of temperature on electrical characteristics of crystalline and amorphous photovoltaic (PV) modules in outdoor conditions at Nawabshah. The experimental setup was made over the roof of the departmental building. The climatic conditions of site were recorded with the help of HP-2000 Professional Weather Station in three different timings of the day, i.e. morning, noon and evening. The electrical characteristics of the PV modules were recorded with Prova210 and module temperatures with Prova-830. The maximum intensity of global solar radiation was recorded at noon and ambient temperature in the evening and the relative humidity in the morning hours. It was observed that amorphous module got $0.7^{\circ} \mathrm{C}, 1.0^{\circ} \mathrm{C}$ and $1.6^{\circ} \mathrm{C}$ more average temperature than polycrystalline, thin film and monocrystalline modules respectively. The average maximum measured open-circuit voltage was noted from amorphous with $96.7 \%$ and minimum from thin film with $81.3 \%$ of their respective values on standard conditions, whereas, the average maximum recorded short-circuit current was produced by thin film with $64.9 \%$ and minimum by amorphous with $51.4 \%$. The average maximum power was produced by polycrystalline and minimum by amorphous module. It was discovered that the crystalline PV modules gave more fill factor than thin film and amorphous module.
\end{abstract}

Keywords: Climatic conditions; Module temperature; I-V characteristics; Photovoltaic module; Power output

Article History: Received January $6^{\text {th }}$ 2018; Received in revised form May $5^{\text {th }}$ 2018; Accepted May 26 ${ }^{\text {th }}$ 2018; Available online

How to Cite This Article: Jatoi, A.R., Samo, S.R. and Jakhrani, A.Q. (2018). Influence of Temperature on Electrical Characteristics of Different Photovoltaic Module Technologies. Int. Journal of Renewable Energy Development, 7(2), 85-91.

https://doi.org/10.14710/ijred.7.2.85-91

\section{Introduction}

Pakistan is suffering from acute energy crisis since last decade. At present, the gap between energy demand and supply is being fulfilled through blackouts and the country falls into darkness from ten to twelve hours per day. The shortfalls reached up to $4.5 \mathrm{GW}$ in 2010, 6.620GW in 2012, and 5.2GW 2013 (Rafique and Rehman, 2017; Shakeel et al. 2016; Asif 2009; Asif and Muneer, 2007). If Pakistan is unable to balance its demand and supply, it will further aggravate the situation. However, the renewable energy resources like hydropower, wind and solar can be utilized to fulfill increasing energy demand (Farooq and Shakoor, 2013).

Solar energy is one of the most commanding renewable energy source, environment and naturefriendly, and does not produce emissions that contribute greenhouse effect or destroy the ecological balance of the area (Jakhrani et al. 2013; Belmonte 2009). Luckily, Pakistan is receiving huge amount of solar radiations with $3.75 \mathrm{kWh} / \mathrm{m}^{2} /$ day in December to $6.42 \mathrm{kWh} / \mathrm{m}^{2} /$ day in May with an annual average of $5.24 \mathrm{kWh} / \mathrm{m}^{2} /$ day (NASA 2013). Solar energy can be converted into electricity indirectly through the use of thermal systems and directly by Photovoltaic (PV) modules (Kalogirou 2014; Duffie and Beckman, 2013). Photovoltaic (PV) modules are usually influenced by a number of factors, such as available solar radiation, ambient temperature, wind speed, latitude of the location, operating conditions of module, rain, dust, types of encapsulating material, thermal absorption, dissipation properties, types, configuration and time of the day (Ali et al. 2017; Ghani et al. 2015; Jakhrani et al. 2011a; Jakhrani et al. 2011b).

PV modules are generally rated under standard test conditions (STC) with the solar radiation of $1000 \mathrm{~W} / \mathrm{m}^{2}$, cell temperature of $25^{\circ} \mathrm{C}$, and solar spectrum of 1.5 by the manufacturers (Sarkar 2016; Jakhrani et al. 2014). These values may not match with the measurement in actual operating conditions due to random nature of climatic conditions (Fuentes et al. 2007; Soto et al. 2006).

Generally, the efficiency of a monocrystalline silicon solar cell is around $14-15 \%$, polycrystalline $12-13 \%$ and amorphous 6-7\% (Kalogirou 2014). PV module performance is usually inversely proportional to the operating temperature of cell because increase of temperature reduces the band gap of a PV cell and increases the energy of the electrons in the material. Since the STC is seldom encountered, the Current-

\footnotetext{
*Corresponding author: arjatoi@quest.edu.pk
} 
Citation: Jatoi, A.R., Samo, S.R. and Jakhrani, A.Q. (2018). Influence of Temperature on Electrical Characteristics of Different Photovoltaic Module Technologies. Int. Journal of Renewable Energy Development, 7(2), 85-91, doi.org/10.14710/ijred.7.2.85-91

$\mathrm{P}$ a g e $\mid 86$

Voltage (I-V) curve of a PV cell describes its actual energy conversion capability at any existing conditions of light level (irradiance) and temperature (Alami 2014; Almaktar et al. 2013; Duffie and Beckman, 2013; Jakhrani et al. 2011b; García and Balenzategui, 2004). PV cells give their maximum performance in cold climate and sunny skies rather than cloudy and hot climates (Arjyadhara et al. 2013). In summer, panel's temperature typically ranges from 40 to $70^{\circ} \mathrm{C}$ which makes a 7.5 to $22.5 \%$ drop in the conversion rate (Biwole et al. 2011). The efficiency of PV cells usually decreases by $0.2 \%$ to $0.5 \% /{ }^{\circ} \mathrm{C}$ with the rise of ambient temperature beyond nominal cell operating temperature (NOCT) (Jakhrani et al. 2017; Eveloy et al. 2012; Skoplaki et al. 2008; Marion 2008; King 1997). It is crucial to know the actual effect of climatic conditions on the performance of PV modules due to installation of $\mathrm{PV}$ systems in different environments (Jakhrani et al. 2014). This study is conducted to quantify the influence of climatic parameters, particularly solar radiation and temperature on the electrical characteristics of different photovoltaic module technologies at outdoor conditions of Nawabshah.

\section{Materials and Methods}

The electrical characteristics, such as current-voltage (I-V) and power-voltage (P-V) of crystalline (mono and poly) and non-crystalline (amorphous and double junction thin film) PV modules were examined at Nawabshah, Pakistan. Their specifications are given in Table 1. The modules were oriented towards true south at the slope of $12^{\circ}$ with respect to horizontal as shown in Fig. 1.

Table 1

Electrical characteristics of examined modules

\begin{tabular}{|c|c|c|c|c|c|}
\hline \multirow{3}{*}{$\begin{array}{c}\text { Module } \\
\text { Parameters }\end{array}$} & \multirow{2}{*}{ Unit } & \multicolumn{4}{|c|}{ Module Technologies } \\
\hline & & (p-Si) & $(\mathrm{m}-\mathrm{Si})$ & (a-Si) & Thin Film \\
\hline & - & SUN 40P & SUN 40M & TPS 40 & GS 50 \\
\hline Voc & $\mathrm{V}$ & 43 & 21.5 & 29 & 62 \\
\hline Isc & $\mathrm{A}$ & 1.29 & 2.55 & 2.3 & 1.42 \\
\hline Vmax & $\mathrm{V}$ & 35 & 17.5 & 18 & 43 \\
\hline Imax & A & 1.14 & 2.29 & 2.2 & 1.17 \\
\hline Pmax & W & 40 & 40 & 40 & 50 \\
\hline Area & $\mathrm{m}^{2}$ & 0.27 & 0.24 & 0.76 & 0.74 \\
\hline
\end{tabular}

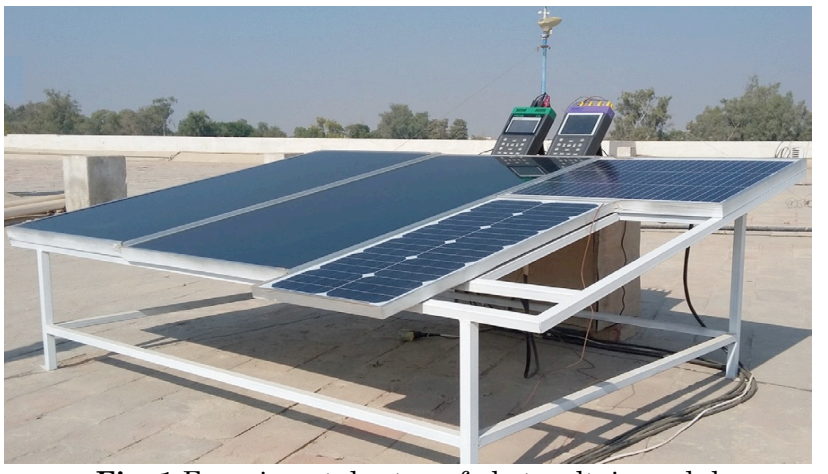

Fig. 1 Experimental setup of photovoltaic modules

The mean global solar radiation, GSR $\left(\mathrm{W} / \mathrm{m}^{2}\right)$, ambient temperature, $\mathrm{Ta}\left({ }^{\circ} \mathrm{C}\right)$, wind speed, $\mathrm{Vw}(\mathrm{m} / \mathrm{s})$, and relative humidity, $\mathrm{RH}(\%)$ were measured with the help of Professional Weather Station, Model HP-2000, on 08:00, 12:00 and 16:00 hours from the month of April till June 2016. Open circuit voltage, Voc (V), short circuit current, Isc (A) and power, Pm (W) of PV modules were recorded with PV Analyzer, Prova-210. The surface and back surface temperature of the modules were recorded with Prova-830. A total of eight K-type thermocouples were used for recording module temperatures. The data loggers were interfaced with computer storing data for further analysis. The PV module temperatures were considered using mean of both surface and back surface temperature of each module as given in Eq. (1) (Jatoi et al. 2016; Huang et al. 2011).

$$
T_{m}=\left(\frac{T_{s}+T_{b s}}{2}\right)
$$

The measured electrical characteristics of examined modules were normalized due to their unequal Voc, Isc and $\mathrm{Pm}$ for comparison and performance analysis. The measured values of modules are normalized by using Eq. (2) and fill factor was computed through Eq. (3) (Jatoi et al. 2016; Sarkar et al. 2016).

$$
\begin{aligned}
& \text { Output }=\left(\frac{\text { Measured Values }}{S \tan \text { dard Values }}\right) \times 100 \\
& F F=\left(\frac{P_{\text {max }}}{V_{o c} \times I_{S C}}\right)
\end{aligned}
$$

\section{Results and Discussions}

Climatic conditions at the site during study period and measured normalized voltage, current, and power output of photovoltaic modules are given as under.

\subsection{Climatic conditions}

The average values of global solar radiation (GSR) during three months period are shown in Fig. 2, and ambient temperature $(\mathrm{Ta})$, wind speed $(\mathrm{Vw})$ and relative humidity $(\mathrm{RH})$ are given in Fig. 3. The mean maximum 
and minimum GSR during study period were $959.3 \mathrm{~W} / \mathrm{m}^{2}$ and $435.7 \mathrm{~W} / \mathrm{m}^{2}$, Ta $41.2^{\circ} \mathrm{C}$ and $29.7^{\circ} \mathrm{C}, \mathrm{Vw} 2.4$ and $1.6 \mathrm{~m} / \mathrm{s}$, and $\mathrm{RH} 54.4$ and $21.7 \%$ respectively. The mean maximum value of GSR was noted at 12:00 hours, Ta at 16:00 hours, and $\mathrm{RH}$ at 08:00 hours. It was observed from the analysis that the intensity of GSR and Ta were increasing linearly from morning till noon, and then decreasing gradually up to the evening. The level of relative humidity was more when ambient temperature was low, and vice versa. It is deduced from the analysis that the relative humidity is inversely proportional to the intensity of global solar radiation and ambient temperature during study period in outdoor conditions at Nawabshah.

\subsection{Photovoltaic modules temperature}

Fig. 4 demonstrates the values of all examined photovoltaic (PV) modules temperatures (Tm). The mean recorded maximum temperature of polycrystalline (Tmp), monocrystalline (Tmm), amorphous (Tma) and thin film (Tmt) PV modules were $61.1,59.9,61.9$ and $59.9^{\circ} \mathrm{C}$ respectively when the level of GSR was $959.3 \mathrm{~W} / \mathrm{m}^{2}$ and Ta was $38.5^{\circ} \mathrm{C}$. At $12: 00$ hours, the amorphous PV module gained $0.8^{\circ} \mathrm{C}$ temperature more than polycrystalline, $2.1^{\circ} \mathrm{C}$ than monocrystalline and $2.0^{\circ} \mathrm{C}$ than thin film modules. Besides amorphous, the polycrystalline module acquired $1.2^{\circ} \mathrm{C}$ more temperature than monocrystalline and thin film modules.

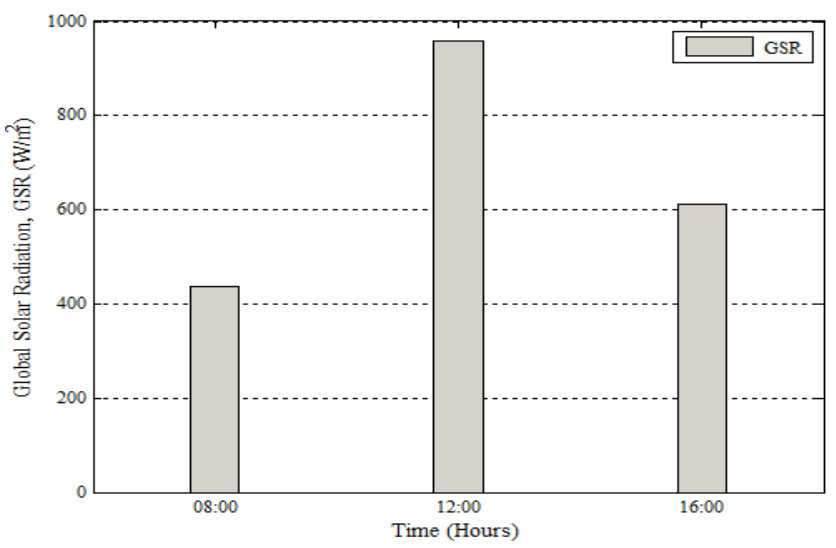

Fig. 2 Global solar radiation at different time of the day

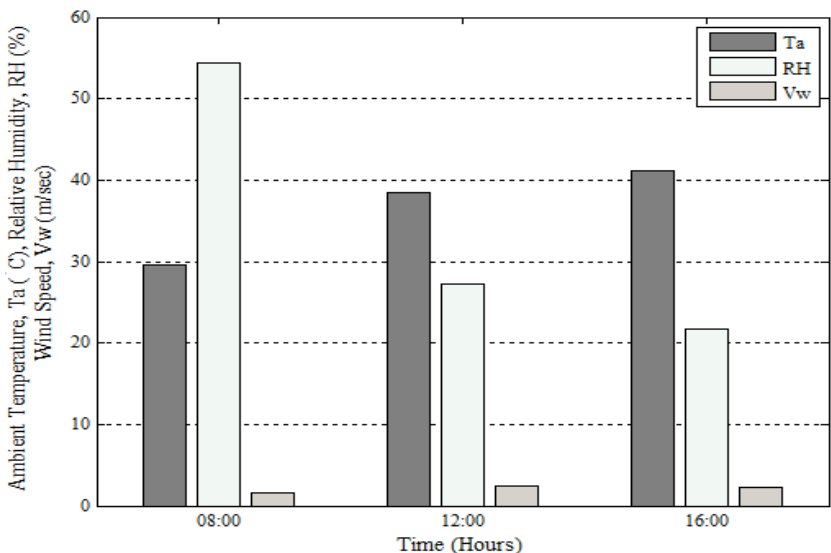

Fig. 3 Ambient temperature, relative humidity and wind speed at different time of the day

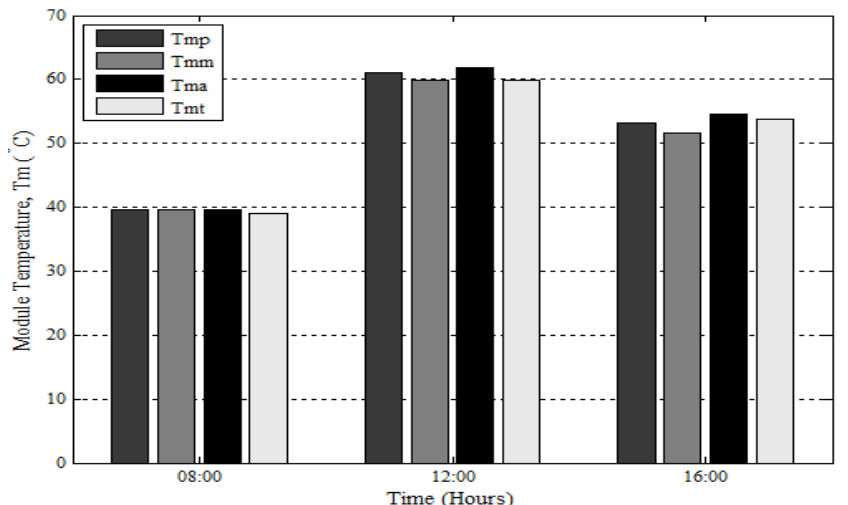

Fig. 4 Photovoltaic modules temperature at different time of the day

The sequence of maximum temperature gain to minimum was acquired by amorphous, polycrystalline, monocrystalline and thin film in the entire day, while the monocrystalline module gained more temperature than thin film at morning time, and thin film module obtained more temperature than monocrystalline from noon to evening, and vice versa.

\subsection{Electrical characteristics of photovoltaic modules}

Electrical characteristics, such as, open-circuit voltage (Voc), short-circuit current (Isc), and power output $(\mathrm{Pm})$ of all examined PV modules were recorded at three different timings of the day at 08:00, 12:00 and 16:00 hours for their performance trend in different periods of time. In addition, the measured output parameters are normalized with their respective rated values for comparative analysis.

\subsubsection{Open-circuit voltage and short-circuit current of modules at 08:00 hours}

The mean measured I-V characteristics of all PV modules at 08:00 hours are given in Fig. 5 and P-V characteristics in Fig. 6. As shown in Fig. 5, the maximum measured open-circuit voltage (Voc) was noted from amorphous with $99.2 \%$ and minimum from thin film with $84.2 \%$ of their respective standard open-circuit voltage conditions. The maximum recorded short-circuit current (Isc) was produced by thin film with $40.7 \%$ and minimum by two modules, namely polycrystalline and amorphous with $30.8 \%$. The measured maximum to minimum level of Voc was produced by amorphous, monocrystalline, polycrystalline and thin film with 99.2, 95.7, 92.2 and $84.2 \%$ respectively. It was revealed from analysis that amorphous PV module generated 3.5, 7.0 and $15.0 \%$ more Voc than monocrystalline, polycrystalline and thin film. While the thin film gave 9.5, 9.9 and 10.0 more Isc than monocrystalline, amorphous and polycrystalline.

Fig. 6 demonstrates the measured P-V characteristics of all PV modules. The maximum power was generated by monocrystalline with $22.6 \%$ and minimum was $17.2 \%$ from amorphous of their respective rated power values. The mean Pm output of all modules was low at this time, because of low intensity of global solar radiations. The maximum to minimum power was produced by monocrystalline, polycrystalline, thin film and 
Citation: Jatoi, A.R., Samo, S.R. and Jakhrani, A.Q. (2018). Influence of Temperature on Electrical Characteristics of Different Photovoltaic Module Technologies. Int. Journal of Renewable Energy Development, 7(2), 85-91, doi.org/10.14710/ijred.7.2.85-91

$\mathrm{P}$ a g e $\mid 88$

amorphous with $22.6,21.4,19.3$ and $17.2 \%$ respectively. It was revealed that monocrystalline gives $1.2,3.3$ and 5.4 more mean percentage power than polycrystalline, amorphous and thin film.

\subsubsection{Open-circuit voltage and short-circuit current of modules at 12:00}

The mean measured I-V characteristics at 12:00 hours of all PV modules are given in Fig. 7 and P-V characteristics in Fig. 8. As shown in Fig 7, the maximum open-circuit voltage (Voc) was noted from amorphous with $95.5 \%$ and minimum from thin film with $80.5 \%$ of standard open-circuit voltage conditions. The maximum short-circuit current (Isc) produced by thin film module with 105.3 and minimum by amorphous with $83.3 \%$ at $12: 00$ hours. The higher to lower output values of Voc was given by amorphous, monocrystalline, polycrystalline and thin film with $95.5,92.2,89.4$ and $80.5 \%$ respectively. Likewise, the Isc was given by thin film, polycrystalline, monocrystalline and amorphous with $105.3,90.2,84.7$ and $83.3 \%$ respectively. It was revealed from analysis that amorphous PV module generated 3.3, 6.1 and 15.0 more mean percentage of Voc than monocrystalline, polycrystalline and thin film, and thin film module gave 15.1, 20.6 and $22.0 \%$ more Isc than polycrystalline, monocrystalline and amorphous at 12:00 hours data records.

Fig 8 demonstrates the measured P-V characteristics of all PV modules. The maximum Pm was generated by polycrystalline with $54.6 \%$ and minimum was $40.9 \%$ by amorphous of their standard power values. The mean Pm outputs of all modules were found high at this time, because of maximum intensity of global solar radiations. The mean maximum to minimum power was recorded from polycrystalline, monocrystalline, thin film and amorphous with 54.7, 53.0, 48.8 and $40.9 \%$ respectively. It was noted that polycrystalline gives 1.7, 5.9 and 13.8 more percentage mean power than monocrystalline, thin film and amorphous modules.

It was revealed from the analysis that amorphous and thin film modules are more sensitive with respect to module temperature than polycrystalline and monocrystalline PV modules. Besides that, the overall efficiency of amorphous and thin film PV modules are less than that of polycrystalline and monocrystalline PV modules respectively.

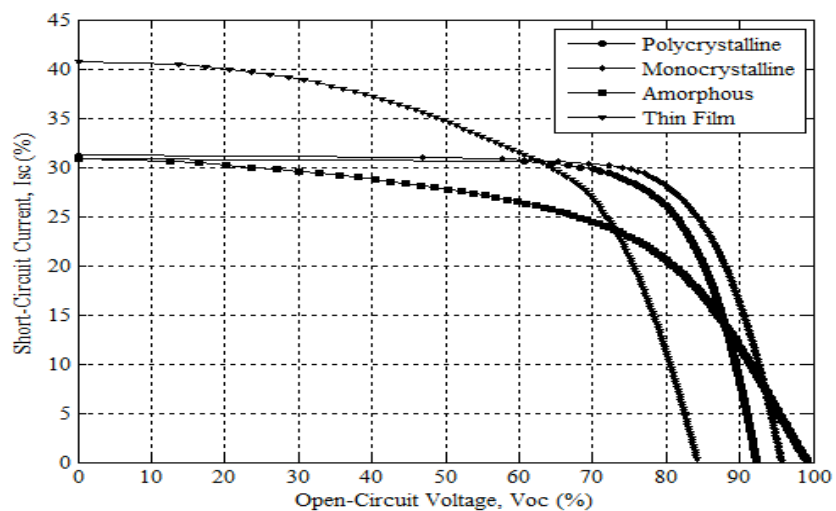

Fig. $5 \mathrm{I}-\mathrm{V}$ curve of examined photovoltaic modules at 08:00 hours

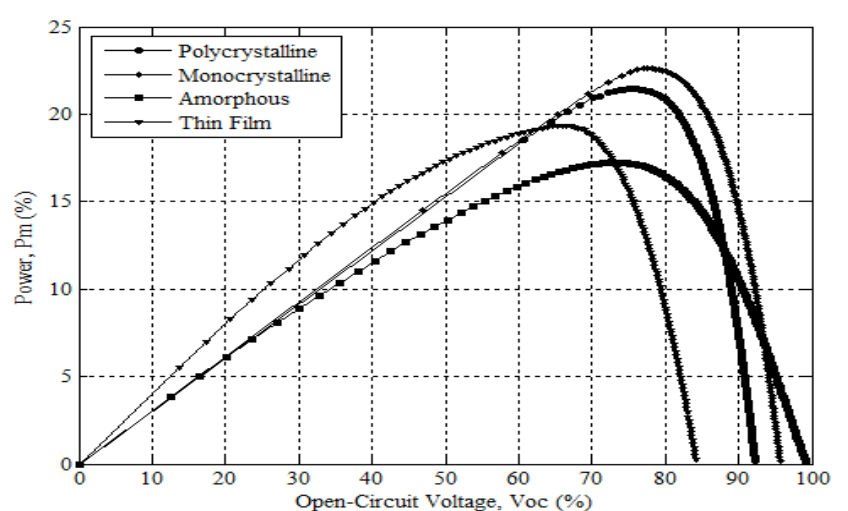

Fig. 6 P-V curve of examined photovoltaic modules at 08:00 hours

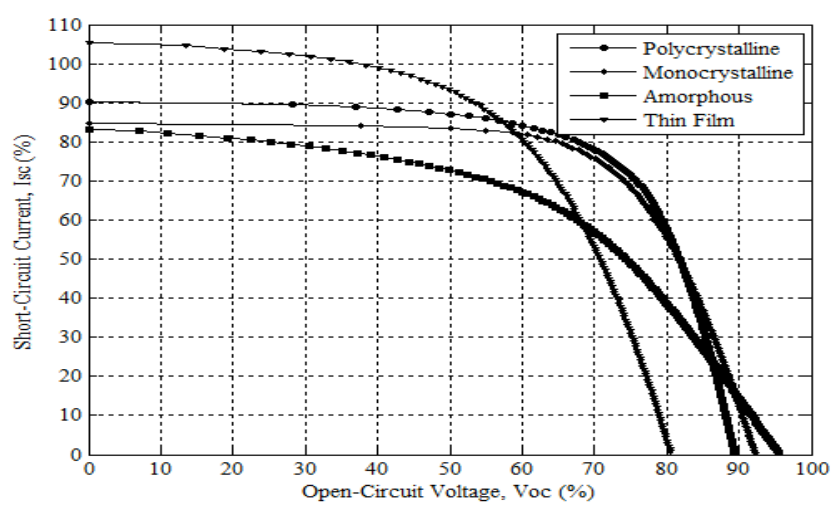

Fig. 7 I-V curve of examined photovoltaic modules at 12:00 hours

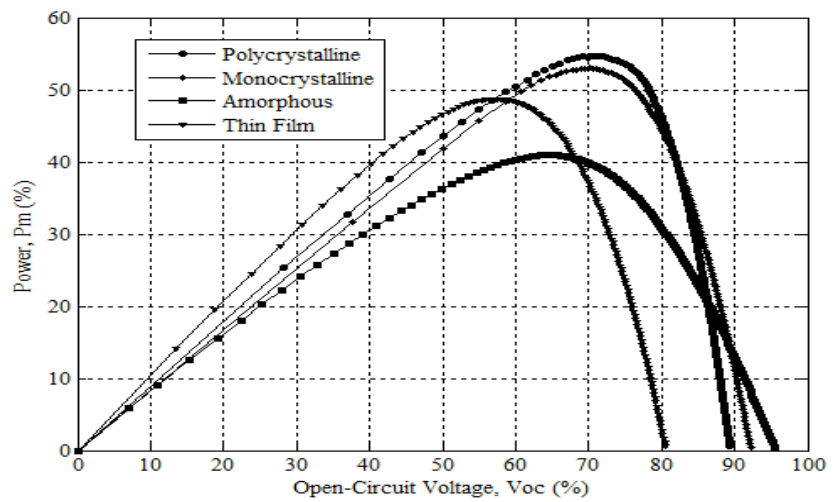

Fig. 8 P-V curve of examined photovoltaic modules at 12:00 hours

\subsubsection{Open-circuit voltage and short-circuit current of modules at 16:00 hours}

The mean measured I-V characteristics at 16:00 hours of all PV modules are given in Fig. 9 and P-V characteristics in Fig. 10. As shown in Fig. 9, the maximum open-circuit voltage (Voc) was noted from amorphous with $95.2 \%$ and minimum from thin film with $79.3 \%$ of their respective standard open-circuit voltage conditions. The mean maximum short-circuit current (Isc) was produced by thin film module with 48.7 and minimum by amorphous with $40.0 \%$.

The maximum to minimum trend of Voc showed by amorphous, monocrystalline, polycrystalline and thin film with 95.2, 92.2, 88.9 and $79.3 \%$ respectively. 
Likewise, higher to lower trend of Isc values were shown by thin film, polycrystalline, monocrystalline and amorphous with $48.7,48.0,43.4$ and $40.0 \%$ respectively of their respective standard conditions. It was exposed from analysis that the amorphous PV module gave 3.0, 6.3 and 15.9 more mean percentage of Voc than monocrystalline, polycrystalline and thin film. Moreover, thin film PV module gave 0.7, 5.3 and 8.7 more percentage of mean Isc than polycrystalline, monocrystalline and amorphous.

Fig. 10 demonstrates the measured P-V characteristics of all PV modules during 16:00 hours. The mean $\mathrm{Pm}$ was generated by polycrystalline with $31.0 \%$ and minimum $21.4 \%$ from amorphous of their respective standard power values. The mean Pm output of all modules was again low at this time, because of low intensity of global solar radiations. The maximum to minimum level of power was noted from polycrystalline, monocrystalline, thin film and amorphous with 31.0, $29.2,23.4$ and $21.4 \%$ of their respective standard conditions respectively. It was noted that polycrystalline gives 1.8, 7.7 and 9.7 more percentage power than monocrystalline, thin film and amorphous PV modules respectively.

\subsubsection{Average electrical characteristics of modules}

The average values of I-V and P-V of all examined modules during different timings of the days are given in Figs 11 and 12. As shown in Fig. 11, the maximum average open-circuit voltage (Voc) was noted from amorphous with $96.7 \%$ and minimum from thin film with $81.3 \%$ of their respective standard conditions. The average maximum short-circuit current (Isc) was produced by thin film module with 64.9 and minimum by amorphous with $51.4 \%$. The maximum to minimum trend of average Voc showed by amorphous, monocrystalline, polycrystalline and thin film with 96.7, 93.4, 90.1 and $81.3 \%$ respectively. Likewise, higher to lower trend of average Isc values were shown by thin film, polycrystalline, monocrystalline and amorphous with $64.9,56.3,53.1$ and $51.4 \%$ respectively of their respective standard conditions. It was also found that the amorphous module generated 3.4, 6.6 and $15.4 \%$ more average Voc than monocrystalline, polycrystalline and thin film respectively, whereas, the thin film module gave $8.6,11.8$ and $13.5 \%$ more average Isc than polycrystalline, monocrystalline and amorphous respectively.

Fig. 12 demonstrates the measured P-V characteristics output of all PV modules. The average Pm was generated by polycrystalline with $36.3 \%$ and minimum $26.5 \%$ from amorphous of their respective standard power values. The maximum to minimum average of $\mathrm{Pm}$ was noted from polycrystalline, monocrystalline, thin film and amorphous with 36.3 , $34.9, \quad 30.2$ and $26.5 \%$ of their respective standard conditions respectively.

It was noted that polycrystalline gives $1.5,6.1$ and 9.8 more average percentage of power than monocrystalline, thin film and amorphous PV modules respectively. Polycrystalline module gave 1.5 more of average percentage of power than monocrystalline and thin film gave $3.8 \%$ more average percentage of power than amorphous.

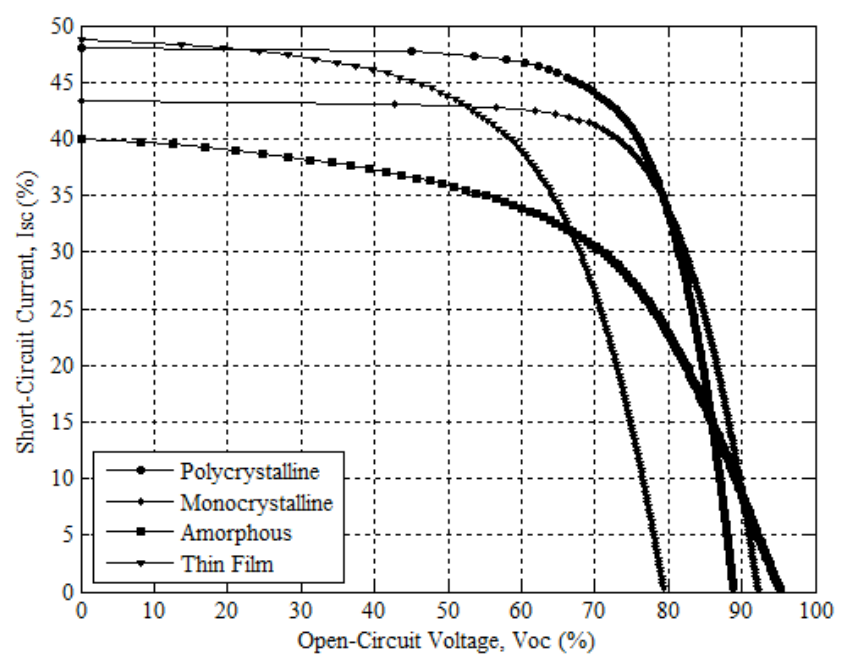

Fig. 9 I-V curve of examined photovoltaic modules at 16:00 hours

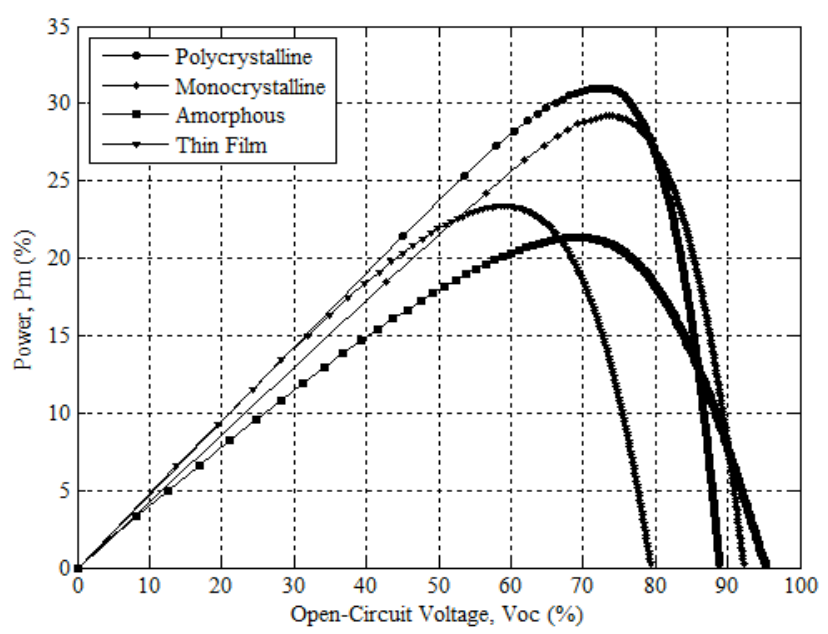

Fig. 10. P-V curve of examined photovoltaic modules at 16:00 hours

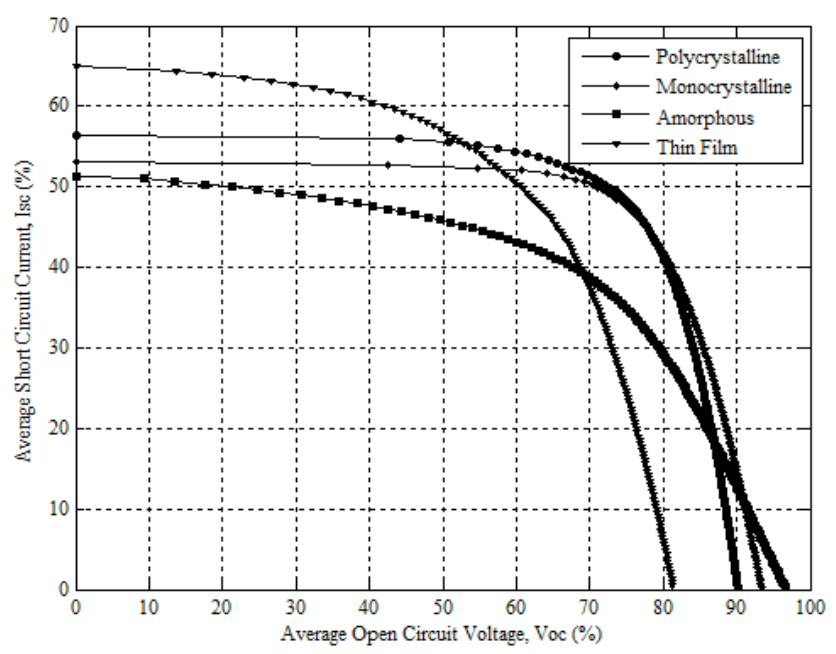

Fig. 11 Average I-V curve of selected photovoltaic modules 


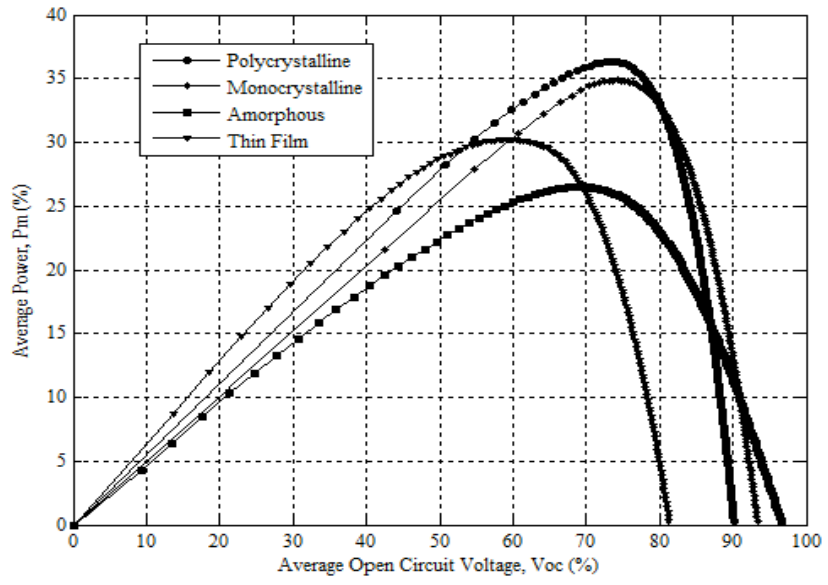

Fig. 12 Average P-V curve of selected photovoltaic modules

\subsubsection{Fill factor of selected PV modules from rated conditions}

The recorded fill factor (FF) of all examined modules during different timings of the days is given in Fig. 13. It is observed from the analysis that both polycrystalline and monocrystalline gave maximum fill factor values with 0.76, and minimum fill factor from amorphous module with 0.56 of their respective rated values at 08:00 hours. Higher to lower trend of fill factor was noted from polycrystalline, monocrystalline, thin film and amorphous respectively. Moreover, polycrystalline and monocrystalline exhibited 0.19 and 0.2 more fill factor than thin film and amorphous respectively during study period.

Similarly, the mean maximum fill factor was noted from polycrystalline with 0.70 and minimum from amorphous module with 0.52 of their rated values at 12:00 hours. The higher to lower trend of fill factor was noted from polycrystalline, monocrystalline, thin film and amorphous with $0.70,0.69,0.58$ and 0.52 respectively. It was seen that polycrystalline gave 0.01 , 0.12 and 0.18 more fill factor than monocrystalline, thin film and amorphous respectively. Moreover, the mean maximum FF was noted from both polycrystalline and monocrystalline with 0.73 and minimum from amorphous module with 0.56 of their rated values at 16:00 hours. The higher to lower trend of fill factor was noted from polycrystalline, monocrystalline, thin film and amorphous with $0.73,0.73,0.61$ and 0.56 respectively. It was revealed from the analysis that the fill factor of polycrystalline and monocrystalline was 0.12 and 0.17 more than thin film and amorphous modules respectively during 16:00 hours data recordings.

It was found from analysis that polycrystalline, monocrystalline, amorphous and thin film modules gave same fill factor at morning and evening (08:00 and 16:00 hours) data recording periods, but at the noon, the maximum fill factor was noted from polycrystalline with 0.70 , monocrystalline 0.69 , thin film 0.58 and minimum from amorphous with 0.52 .

In general, the crystalline (i.e. polycrystalline and monocrystalline) photovoltaic modules gave 0.14 and 0.18 more average fill factor than thin film and amorphous modules respectively.

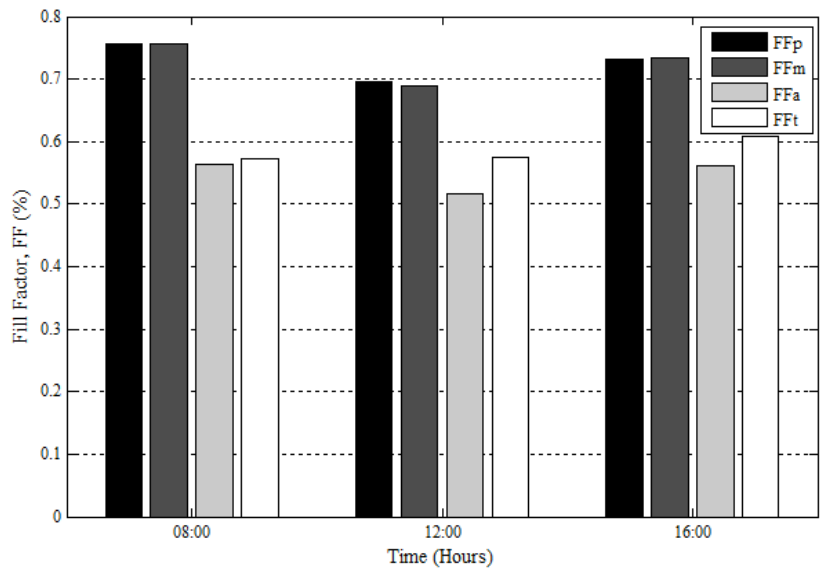

Fig. 13 Fill Factor of all selected PV modules from rated conditions

\section{Conclusions}

The mean maximum recorded global solar radiation during study period was $959.3 \mathrm{~W} / \mathrm{m}^{2}$, ambient temperature $41.2^{\circ} \mathrm{C}$, wind speed $2.4 \mathrm{~m} / \mathrm{s}$ and relative humidity $54.4 \%$. The maximum intensity of global solar radiation was recorded at noon, and ambient temperature was in the evening, and the relative humidity was in the morning. The relative humidity was found inversely proportional to the intensity of global solar radiation and ambient temperature. It was observed that amorphous module attained the highest daily average temperature of $52.0^{\circ} \mathrm{C}$, polycrystalline $51.3^{\circ} \mathrm{C}$, thin film $51.0^{\circ} \mathrm{C}$, and monocrystalline became the lowest with $50.4^{\circ} \mathrm{C}$, throughout the study period. It showed that amorphous got $0.7^{\circ} \mathrm{C}, 1.0^{\circ} \mathrm{C}$ and $1.6^{\circ} \mathrm{C}$ more average temperature than polycrystalline, thin film and monocrystalline modules respectively. It was also found that the amorphous module generated 3.4, 6.6 and 15.4\% more average $\mathrm{V}_{\mathrm{oc}}$ than monocrystalline, polycrystalline and thin film respectively, whereas, the thin film module gave $8.6, \quad 11.8$ and $13.5 \%$ more average Isc than polycrystalline, monocrystalline and amorphous respectively. On the other hand, the average maximum power was produced by polycrystalline with $36.3 \%$, whereas, monocrystalline gave $34.9 \%$, thin film $30.2 \%$ and amorphous generated minimum power with $26.5 \%$ of their respective rated power values. Polycrystalline module gave 1.5 more percentage of average power than monocrystalline, and thin film gave $3.8 \%$ more average power than amorphous. It was also exposed from the analysis that crystalline module has same average fill factor with 0.73 , and amorphous gave minimum fill factor of 0.55 . It showed that the crystalline photovoltaic modules gave 0.14 more fill factor than thin film and 0.18 more than amorphous module.

\section{Acknowledgements}

The authors would like to acknowledge the financial support provided by the authorities of Quaid-e-Awam University of Engineering Science and Technology, (QUEST), Nawabshah, Pakistan for conducting this research. 


\section{References}

Alami, A.H. (2014) Effects of evaporative cooling on efficiency of photovoltaic modules. Energy Conversion and Management, 77: 668-679.

Ali, H., Zahar, M.A., Bashir, M.A., Nasir, M.A., Ali, M. \& Siddiqui, A.M. (2017) Effect of dust deposition on the performance of photovoltaic modules in Taxila, Pakistan. Thermal Science, 21(2), 915-923.

Almaktar, M., Rahman, H. A., Hassan, M.Y. \& Rahman, S. (2013) Climate-based empirical model for PV module temperature estimation in tropical environment. Applied Solar Energy, 49(4), 192-201.

Arjyadhara, P., Ali, S.M. \& Chitralekha, J. (2013) Analysis of solar PV cell performance with changing irradiance and temperature. International Journal of Engineering and Computer Science, 2(1), 214-220.

Asif, M. \& Muneer, T. (2007) Energy supply, its demand and security issues for developed and emerging economies. Renewable and Sustainable Energy Reviews, 11(7), 13881413.

Asif, M. (2009) Sustainable energy options for Pakistan. Renewable and Sustainable Energy Reviews, 13(4), 903-909.

Belmonte, S., Núñez, V., Viramonte, J. G. \& Franco, J. (2009) Potential renewable energy resources of the Lerma Valley, Salta, Argentina for its strategic territorial planning. Renewable and Sustainable Energy Reviews, 13(6), 14751484.

Biwole, P., Eclache, P. \& Kuznik, F. (2011) Improving the performance of solar panels by the use of phase-change materials. In World Renewable Energy Congress-Sweden, Linköping University Electronic Press, 57, 2953-2960.

Duffie, J.A. \& Beckman, W.A. (2013) Solar engineering of thermal processes, Fourth Edition, New York: Wiley. 745770 .

Eveloy, V., Rodgers, P. \& Bojanampati, S. (2012) Enhancement of Photovoltaic Solar Module Performance for Power Generation in the Middle East. In Semiconductor Thermal Measurement and Management Symposium (SEMITHERM), 28th Annual IEEE, 87-97.

Farooq, M. \& Shakoor, A. (2013) Severe energy crises and solar thermal energy as a viable option for Pakistan. Journal of Renewable and Sustainable Energy, 5(1), 013104-013111.

Fuentes, M., Nofuentes, G., Aguilera, J., Talavera, D.L. \& Castro, M. (2007) Application and validation of algebraic methods to predict the behaviour of crystalline silicon PV modules in Mediterranean climates. Solar Energy, 81(11), 1396-1408.

García, M.A. \& Balenzategui, J.L. (2004) Estimation of photovoltaic module yearly temperature and performance based on nominal operation cell temperature calculations. Renewable Energy, 29: 1997-2010.

Ghani, F., Rosengarten, G., Duke, M. \& Carson, J.K. (2015) On the influence of temperature on crystalline silicon solar cell characterisation parameters. Solar Energy, 112: 437-445.

Huang, B. J., Yang, P. E., Lin, Y. P., Lin, B. Y., Chen, H. J., Lai, R. C. \& Cheng, J. S. (2011) Solar cell junction temperature measurement of PV module. Solar Energy, 85(2), 388-392.

Jakhrani, A. Q., Jatoi, A. R. \& Jakhrani, S. H. (2017) Analysis and Fabrication of an Active Cooling System for Reducing Photovoltaic Module Temperature. Engineering, Technology \& Applied Science Research, 7(5), pp-1980-1986.

Jakhrani, A. Q., Samo, S. R., Rigit, A. R. H. \& Kamboh, S. A. (2013) Selection of models for calculation of incident solar radiation on tilted surfaces. World Applied Sciences Journal, 22(9), 1334-1343.

Jakhrani, A.Q., Othman, A.K., Rigit, A.R.H. \& Samo, S.R. (2011a) Determination and comparison of different photovoltaic module temperature models for Kuching, Sarawak. IEEE-1st Conference on Clean Energy and Technology (CET), 231-236.
Jakhrani, A.Q., Othman, A.K., Rigit, A.R.H. \& Samo, S.R. (2011b) Comparison of solar photovoltaic module temperature models. World Applied Science Journal, 14: 1-8.

Jakhrani, A.Q., Samo, S.R., Kamboh, S.A., Labadin, J. \& Rigit, A.R.H. (2014) An improved mathematical model for computing power output of solar photovoltaic modules. International Journal of Photoenergy, 1-9.

Jatoi, A.R., Samo, S.R. \& Jakhrani, A.Q. (2016) Influence of ambient temperature and solar radiations on photovoltaic module's temperature and power output. International Journal of Natural \& Engineering Sciences, 10 (2), 43-47.

Kalogirou, S.A. (2014) Solar Energy Engineering: Processes and Systems," Second Edition, Amsterdam: Academic Press: Elsevier. 481-536.

King, D. L. (1997) Photovoltaic module and array performance characterization methods for all system operating conditions. In AIP Conference Proceedings, 394(1), 347-368.

Marion, B. (2008) Comparison of predictive models for photovoltaic module performance. In Photovoltaic Specialists Conference. (PVSC'08). 33rd IEEE, 1-6.

National Aeronautics and Space Administration (NASA). Surface meteorology and Solar Energy: RETScreen, https://eosweb.larc.nasa.gov/cgibin/sse/grid.cgi?email=skip@larc.nasa.gov\&step=1\&lat=26.3 \&lon=68.4\&submit=Submit. Accessed on 14 Sep 2013.

Rafique, M. M. \& Rehman, S. (2017) National energy scenario of Pakistan-Current status, future alternatives, and institutional infrastructure: An overview. Renewable and Sustainable Energy Reviews, 69: 156-167.

Sarkar, M.N.I. (2016) Effect of various model parameters on solar photovoltaic cell simulation: a SPICE analysis. Renewables: Wind, Water, and Solar, 3(13), 1-9.

Shakeel, S. R., Takala, J. \& Shakeel, W. (2016) Renewable energy sources in power generation in Pakistan. Renewable and Sustainable Energy Reviews, 64: 421-434.

Skoplaki, E., Boudouvis, A.G. \& Palyvos, J.A. (2008) A simple correlation for the operating temperature of photovoltaic modules of arbitrary mounting. Solar Energy Materials and Solar Cells, 92(11), 1393-1402.

Soto, W. D., Klein, S. A. \& Beckman, W. A. (2006) Improvement and validation of a model for photovoltaic array performance. Solar Energy, 80, 78-88. 